\title{
Large-Scale Analysis of Cell Cycle Regulators in Urothelial Bladder Cancer Identifies p16 and p27 as Potentially Useful Prognostic Markers
}

\author{
Andrea Brunner ${ }^{\mathrm{a}} \quad$ Irmgard Verdorfer $^{\mathrm{a}} \quad$ Martina Prelog $^{\mathrm{b}} \quad$ Christina Mayerl $^{\mathrm{c}}$ \\ Gregor Mikuz ${ }^{\mathrm{a}}$ Alexandar Tzankov ${ }^{\mathrm{d}}$ \\ ${ }^{a}$ Institute of Pathology, ${ }^{b}$ Department of Pediatrics and ${ }^{C}$ Division of Experimental Pathophysiology and \\ Immunology, Biocenter, Medical University of Innsbruck, Innsbruck, Austria; ${ }^{d}$ Institute of Pathology, \\ University of Basel, Basel, Switzerland
}

\section{Key Words}

Bladder cancer $\cdot$ Prognosis $\cdot$ Cell cycle

\begin{abstract}
Aims: We investigated the value of multiple cell cycle markers for their prognostic impact on overall survival and recurrence-free survival in urothelial carcinoma (UC). Methods: A tissue microarray consisting of 99 UCs was evaluated for the expression of p53, p16, p21, p27, cyclin D1, cyclin E, Bcl-2, Ki67 and PCNA. Statistical analysis was performed applying Kaplan-Meier and Cox regression models using receiver operator characteristic curves for determination of markers' cutoffs. Results: Expression above the cutoffs of Ki-67, p53 and p27, particularly in high-grade and early-stage UC, was associated with worse overall survival, while expression of p16 indicated a better outcome in low-grade and low-stage tumors. Recurrence-free survival was better in patients with high-grade UC expressing PCNA, p16 and cyclin E, and lowgrade UC expressing Bcl-2 above the cutoffs, but worse in all tumors with high Ki-67. Conclusion: Cell cycle deregulation in $\mathrm{UC}$ is complex and the prognostic value of the various involved proteins should be differentially regarded with respect to this complexity and other tumor characteristics such as grade and stage. Our results point towards the role of p16- and p27-associated pathways in tumor progression
\end{abstract}

\section{KARGER}

Fax +4161306 1234

E-Mail karger@karger.ch

www.karger.com
(C) 2008 S. Karger AG, Basel

$1015-2008 / 08 / 0751-0025 \$ 24.50 / 0$

Accessible online at:

www.karger.com/pat and indicate that, by using standardized approaches for tissue antigen expression, evaluation and cutoff determination, single potentially useful prognostic markers could be identified.

Copyright $\odot 2008$ S. Karger AG, Basel

\section{Introduction}

The normal cell cycle is characterized by the complex interactions of cyclins, cyclin-dependent kinases and their inhibitors [1]. Though the cell cycle regulation is not fully understood, the prognostic value of cell cycle-regulating proteins in malignant tumors has been widely studied and reported to be of significance in urothelial carcinoma (UC) of the bladder [1-7]. Among the most promising prognostic markers concerning survival, recurrences and progression are those involved in the G1/Sphase transition, such as cyclin D1 (CCND1) and E (CCNE), and cyclin-dependent kinase inhibitors, such as p27, p16 and p21, as well as p53 [1, 8]. Molecular studies revealed loss of chromosome 9 in up to 50\% of UCs and p16 located at 9p21 was identified as a major target gene in early bladder cancer [9]. Expression of cell cycle markers has been linked to grade, stage and survival, but individual markers so far have not proved to be superior to

Dr. Andrea Brunner

Institute of Pathology, Medical University of Innsbruck

Muellerstrasse 44

AT-6020 Innsbruck (Austria)

Tel. +43 5129003 71306, Fax +43512582 088, E-Mail andrea.brunner@i-med.ac.at 
Table 1. Antibodies, sources, dilutions, pretreatment and staining patterns

\begin{tabular}{|c|c|c|c|c|c|}
\hline Antibody & Source & Clone & Dilution & Pretreatment & Staining pattern \\
\hline Ki-67 & Dako & MIB-1 & $1: 100$ & $\begin{array}{l}\text { wet autoclave; } \\
\text { citrate buffer (pH 6) }\end{array}$ & nuclear \\
\hline PCNA & Dako & PC10 & $1: 300$ & $\begin{array}{l}\text { microwave }(10 \mathrm{~min}, 750 \mathrm{~W}) \text {; } \\
\text { distilled water }\end{array}$ & nuclear \\
\hline p53 & Dako & DO-7 & $1: 50$ & $\begin{array}{l}\text { wet autoclave; } \\
\text { citrate buffer (pH 6) }\end{array}$ & nuclear \\
\hline p21 & Neomarkers & HZ52 & $1: 400$ & $\begin{array}{l}\text { microwave; } \\
\text { citrate buffer ( } \mathrm{pH} \text { 6) }\end{array}$ & nuclear \\
\hline p27 & Dako & SX53G8 & $1: 100$ & $\begin{array}{l}\text { wet autoclave; } \\
\text { citrate buffer ( } \mathrm{pH} \text { 6) }\end{array}$ & nuclear/cytoplasmic \\
\hline p16 & Neomarkers & $\begin{array}{l}16 \mathrm{PO} 4 \\
(\mathrm{JC} 2)\end{array}$ & $1: 50$ & $\begin{array}{l}\text { wet autoclave; } \\
\text { citrate buffer ( } \mathrm{pH} \text { 6) }\end{array}$ & nuclear/cytoplasmic \\
\hline CCND1 & Vector/Al & SP4 & $1: 100$ & $\begin{array}{l}\text { wet autoclave; } \\
\text { citrate buffer ( } \mathrm{pH} \text { 6) }\end{array}$ & nuclear \\
\hline CCNE & Neomarkers & $13 \mathrm{~A} 3$ & $1: 20$ & $\begin{array}{l}\text { microwave; } \\
\text { citrate buffer (pH 6) }\end{array}$ & nuclear \\
\hline Bcl-2 & Dako & 124 & $1: 50$ & $\begin{array}{l}\text { wet autoclave; } \\
\text { citrate buffer }(\mathrm{pH} 6)^{1}\end{array}$ & cytoplasmic \\
\hline
\end{tabular}

classical prognostic parameters [10-13]. Studies on combinations of different markers that might enhance the predictive power, including p53 together with p16, CCND1 and CCNE together with phosphorylated retinoblastoma protein as well as p21 and p27, suggest multiple alterations, especially in invasive UC that might contribute to recurrence, progression and, finally, worse survival $[3-5,14]$. The expression of the antiapoptotic protein Bcl-2 and the proliferation index, assessed by Ki- 67 and PCNA, have been reported to be potentially useful in predicting prognosis as well $[4,5,7,12,14-17]$. Nevertheless, results obtained in different studies remain controversial.

To further assess the prognostic value of these multiple markers in UC and rationally address determination of prognostic cutoff levels applying receiver operator characteristics (ROC)-based methods, a large-scale immunohistochemical study on 99 specimens of patients with UC of the bladder in a tissue microarray (TMA) format was performed.

\section{Material and Methods}

Samples

Ninety-nine primary diagnoses of UC of the bladder, obtained by means of transurethral resection and diagnosed between January 1994 and December 1997 at the Institute of Pathology, Med- ical University of Innsbruck, were included in our study. All cases were reviewed by 2 pathologists (A.B. and G.M.) and reclassified according to the WHO 2004 classification. Our study group consisted of $27 \mathrm{pTa}$ (22 low-grade and 5 high-grade UCs), $33 \mathrm{pT} 1$ (2 low-grade and 32 high-grade UCs), 34 pT2-4 tumors (all highgrade UCs) and 5 carcinomata in situ (CIS). The clinical and pathological characteristics of the 99 patients have been reported elsewhere [18].

\section{TMA Construction}

Samples were brought into a TMA format as previously described [19]. Three tissue cores $(0.6 \mathrm{~mm})$ and, in small specimens, $1-3$ cores were obtained based on tissue amount including superficial, invasive portion tumor and the adjacent stroma.

\section{Immunohistochemistry}

Immunohistochemistry was performed, except for CCNE and p21, which were manually incubated, on an automated immunostainer (Nexes; Ventana), applying the streptavidin-biotin peroxidase technique with diaminobenzidine as chromogen. The antibodies, sources, dilutions, pretreatment and staining patterns are summarized in table 1 . Immunohistochemical staining was evaluated calculating the mean value of the relative proportion (percentage) of positively staining cells of the individual cores of each case based on at least 100 cells/case. For p16 and p27 cytoplasmic staining was also considered as previously reported [20,21].

\section{Statistics}

The Statistical Package of Social Sciences (SPSS 12.0 for Windows) was used. The Spearman rank test was used to test correlations between individual markers. The analysis of variance (ANOVA) was used to compare means between groups. For de- 
Table 2. Number of evaluable cases (n), number of positive cases $\left(n_{\mathrm{p}}\right)$, mean expression and cutoff values for OS and RFS determined by ROC of the studied markers

\begin{tabular}{llllrr}
\hline & $\mathrm{n}$ & $\mathrm{n}_{\mathrm{p}}{ }^{1}$ & \multicolumn{1}{l}{$\begin{array}{l}\text { Mean } \\
\text { expression }\end{array}$} & $\begin{array}{l}\text { Cutoff } \\
\text { OS, \% }\end{array}$ & $\begin{array}{r}\text { Cutoff } \\
\text { RFS, \% }\end{array}$ \\
\hline Ki-67 & 93 & $91(98)$ & $26.75 \pm 20.81$ & 9.5 & 8.75 \\
PCNA & 89 & $88(99)$ & $58.60 \pm 31.82$ & 58 & 74 \\
p53 & 93 & $43(46)$ & $20.16 \pm 31.47$ & 14 & 4.5 \\
p21 & 92 & $91(99)$ & $93.14 \pm 19.46$ & 98 & 98 \\
p27 & 90 & $46(46)$ & $8.82 \pm 16.42$ & 5.5 & 4.5 \\
p16 & 93 & $42(45)$ & $18.22 \pm 30.29$ & 1.5 & 23 \\
CCND1 & 89 & $35(39)$ & $8.07 \pm 17.20$ & 0.15 & 7 \\
CCNE & 94 & $66(70)$ & $18.94 \pm 23.07$ & 8.5 & 0.2 \\
Bcl-2 & 91 & $52(57)$ & $14.12 \pm 19.70$ & 13.15 & 1.55 \\
\hline
\end{tabular}

${ }^{1}$ Figures in parentheses are percentages.

${ }^{2}$ Data are presented as mean percentages $\pm \mathrm{SD}$.

Table 3. Correlations between different markers

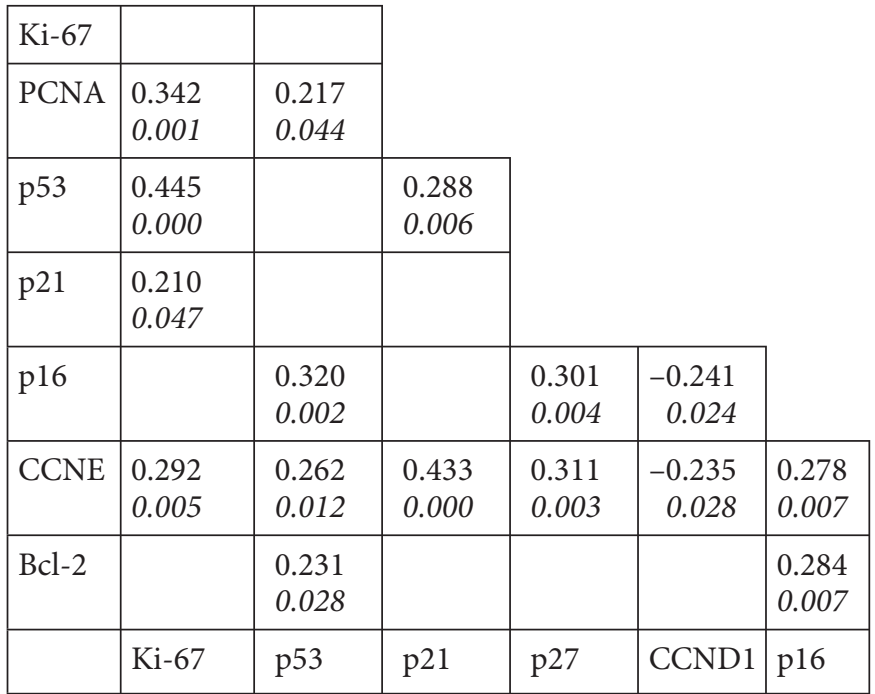

Calculated by Spearman rank test. The upper figures are correlation coefficients, the lower italicized figures are $\mathrm{p}$ values.

termination of optimal cutoff values of continuous variables, ROC curves by plotting sensitivity versus 1 - specificity were used. The optimal cutoff point was calculated using Youden's in$\operatorname{dex}(\mathrm{Y})$ [22]. Overall survival (OS) and recurrence-free survival (RFS) were analyzed by the Kaplan-Meier method applying the cutoff values calculated by ROC/Y and compared by the log rank test, except for continuous variables, where a Cox regression model was applied. Multivariate analysis was performed to identify independent prognostic markers for OS and RFS using a Cox multistep regression model. $\mathrm{p}<0.05$ was considered significant.

p16 and p27 Are Potentially Useful Prognostic Markers in Bladder Cancer
Table 4. ROC and Kaplan-Meier analysis for markers showing prognostic significance concerning OS and RFS

\begin{tabular}{|c|c|c|c|c|c|}
\hline & \multicolumn{3}{|l|}{ ROC } & \multicolumn{2}{|c|}{ Kaplan-Meier analysis } \\
\hline & AUROC & $\mathrm{p}$ value & cutoff, $\%$ & median OS & $\mathrm{p}^{\log \text { rank }}$ \\
\hline Ki-67 & 0.571 & 0.287 & $\begin{array}{l}>9.5 \\
<9.5\end{array}$ & $\begin{array}{r}30 \\
118\end{array}$ & $0.004^{*}$ \\
\hline p53 & 0.536 & 0.593 & $\begin{array}{l}>14 \\
<14\end{array}$ & $\begin{array}{l}17 \\
62\end{array}$ & $0.047^{*}$ \\
\hline p27 & 0.564 & 0.351 & $\begin{array}{l}>5.5 \\
<5.5\end{array}$ & $\begin{array}{l}31 \\
57\end{array}$ & $0.03^{*}$ \\
\hline p16 & 0.584 & 0.213 & $\begin{array}{l}>1.5 \\
<1.5\end{array}$ & $\begin{array}{l}64 \\
35\end{array}$ & 0.087 \\
\hline \multirow[t]{2}{*}{ CCND1 } & 0.663 & $0.021^{*}$ & $\begin{array}{l}>0.15 \\
<0.15\end{array}$ & $\begin{array}{l}64 \\
31\end{array}$ & 0.065 \\
\hline & & & & median RFS & $\mathrm{p}^{\log \text { rank }}$ \\
\hline $\mathrm{Ki}-67$ & 0.516 & 0.793 & $\begin{array}{l}>8.5 \\
<8.5\end{array}$ & $\begin{array}{l}10 \\
88\end{array}$ & $0.018^{*}$ \\
\hline PCNA & 0.599 & 0.11 & $\begin{array}{l}>74 \\
<74\end{array}$ & $\begin{array}{l}90 \\
12\end{array}$ & $0.023^{*}$ \\
\hline p16 & 0.587 & 0.154 & $\begin{array}{l}>23 \\
<23\end{array}$ & $\begin{array}{l}80 \\
12\end{array}$ & $0.027^{*}$ \\
\hline CCNE & 0.603 & 0.09 & $\begin{array}{l}>0.2 \\
<0.2\end{array}$ & $\begin{array}{r}71 \\
9\end{array}$ & $0.014^{*}$ \\
\hline $\mathrm{Bcl}-2$ & 0.60 & 0.106 & $\begin{array}{l}>1.55 \\
<1.55\end{array}$ & $\begin{array}{l}71 \\
38\end{array}$ & $0.003^{*}$ \\
\hline
\end{tabular}

AUROC $=$ Area under ROC curve. ${ }^{*} \mathrm{p}<0.05$.

\section{Results}

\section{TMA Quality}

Three tissue cores/case could be arrayed in 90 cases, whereas 2 and 1 core could be obtained in 6 and 3 cases, respectively, resulting in a total number of 285 cores. After immunohistochemistry, between 225 (79\%) and 262 (92\%) cores and between $89(90 \%)$ and 94 (95\%) cases could be evaluated.

\section{Expression and Correlations}

The number of evaluable cases, the number of positive cases and the mean percentage \pm SD of positively staining cells, as well as the cutoffs for OS and RFS are summarized in table 2. Nuclear and cytoplasmic expression of p16 was found in all positively staining specimens, while p27 expression was mainly restricted to the nuclei with only 6 specimens exhibiting additional cytoplasmic staining (fig. 1). The correlations between markers are shown in table 3. Compared with clinical and pathological parameters, such as age, grade, stage, recurrence and 

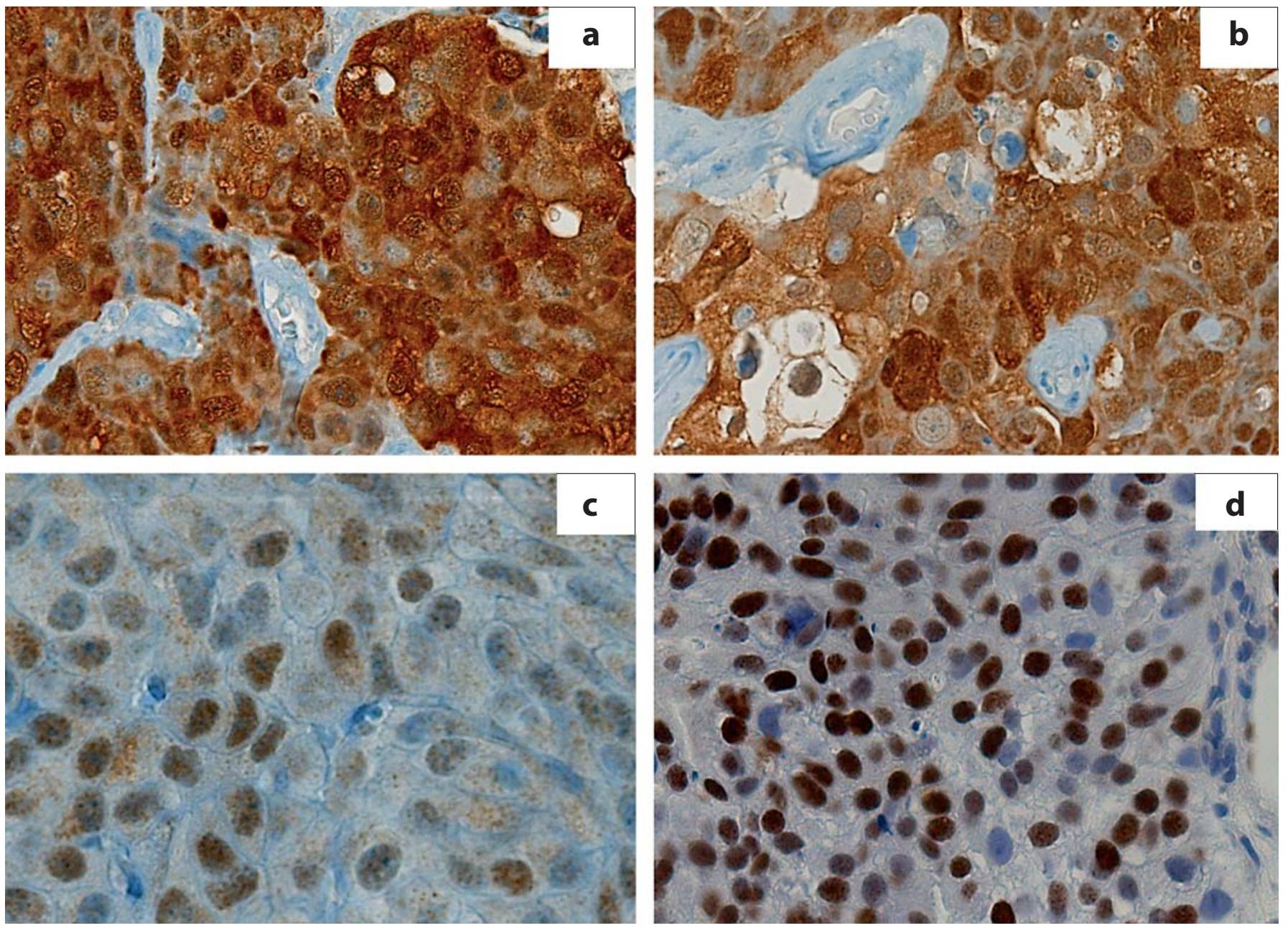

Fig. 1. High-grade bladder cancer with nuclear and cytoplasmic expression of p16 (a, b; $\times 200$ and $\times 400)$; lowgrade bladder cancer with nuclear p27 expression and slight cytoplasmic staining $(\mathbf{c} ; \times 400)$ as well as strong nuclear expression of CCNE in a high-grade tumor $(\mathbf{d} ; \times 200)$.

disease progression, only Ki-67, PCNA and p53 were associated with higher grade $\left(\mathrm{p}^{\text {ANOVA }}<0.001, \mathrm{p}^{\mathrm{ANOVA}}=\right.$ 0.001 and $\mathrm{p}^{\mathrm{ANOVA}}=0.001$, respectively) and stage $\left(\mathrm{p}^{\mathrm{ANOVA}}\right.$ $<0.001, \mathrm{p}^{\mathrm{ANOVA}}=0.021$ and $\mathrm{p}^{\mathrm{ANOVA}}<0.001$, respectively). $\mathrm{Ki}-67$ and CCND1 expression were higher in tumors with subsequent disease progression $\left(\mathrm{p}^{\mathrm{ANOVA}}=0.042\right.$ and $\mathrm{p}^{\mathrm{ANOVA}}=0.032$, respectively). High CCNE expression correlated with the presence of tumor-associated CIS $\left(\mathrm{p}^{\mathrm{ANOVA}}=0.018\right)$.

\section{Receiver Operator Characteristics}

ROC showed significant discriminatory power considering OS for the expression of CCND1, with an optimal cutoff value of $0.15 \%$ (table 4 ). For all other markers,
ROC curves showed only borderline significance or lacked discriminatory power considering OS (table 4). ROC showed borderline discriminatory significance for RFS for PCNA, CCNE, Bcl-2, p16 and p27, but lacked significant discriminatory power for all other markers (table 4). Cutoff values for all markers considering OS and RFS determined by ROC/Y and used for Kaplan-Meier analysis are shown in table 2 .

\section{Overall Survival}

OS was influenced by age, grade, stage and number of recurrences, but not by tumor-associated CIS and progressive disease [18]. A worse OS was found for Ki-67, p53 and p27 expression above the cutoff (table 4; fig. 2a). 

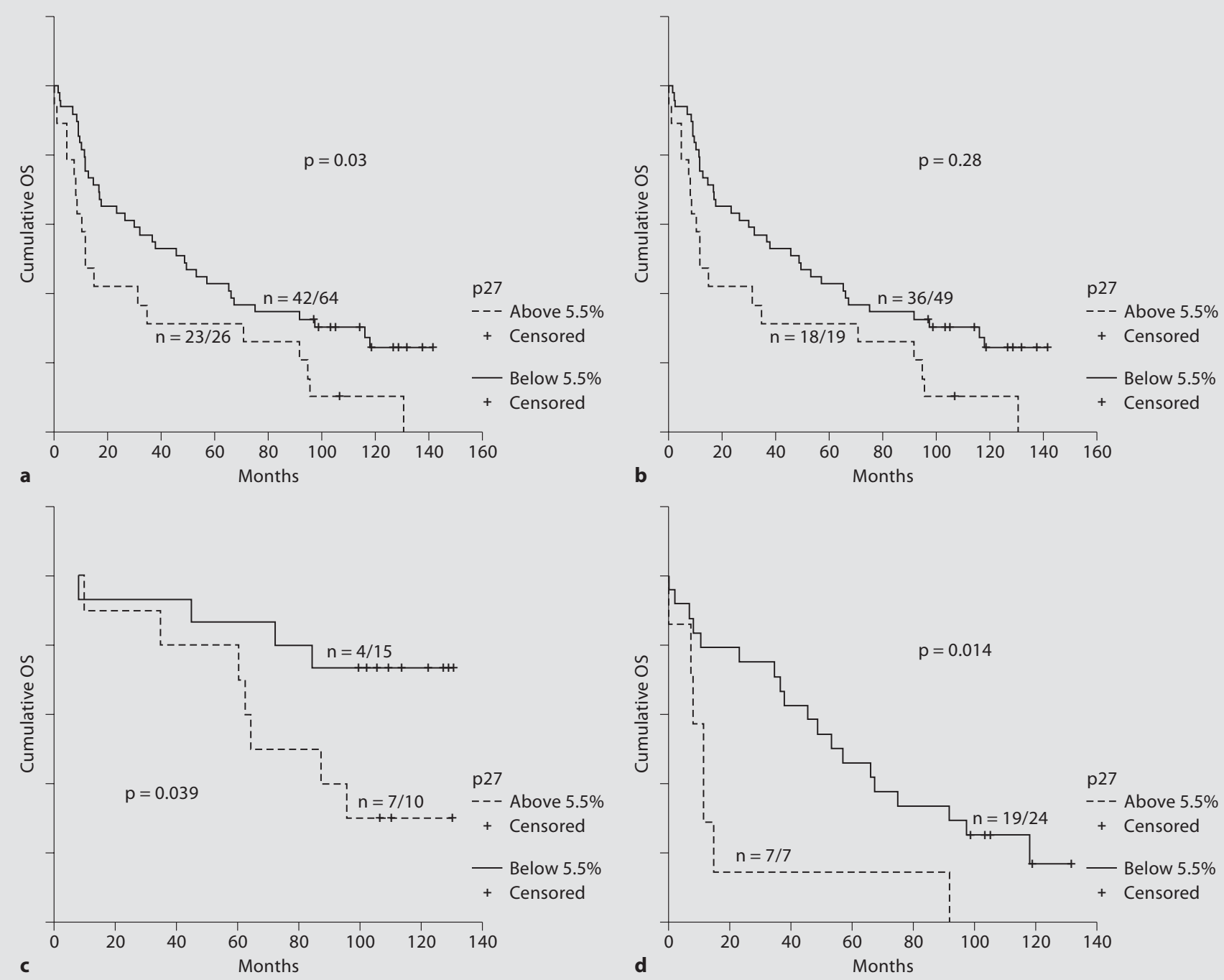

Fig. 2. a Expression of 27 above the cutoff is associated with a worse OS in UC of the bladder. Stratified by grade and stage, p27 expression above the cutoff indicates a worse OS in high-grade (b) as well as in pTa (c) and pT1 (d) tumors. p27 $<5.5 \%$ versus p27 $>5.5 \%$ compared by the log rank test. $n=$ Number of events/number of cases.

Stratified by grade, p27 and Ki-67 expression above the cutoff, but not $\mathrm{p} 53$, were associated with a worse OS in high-grade tumors $\left(\mathrm{p}^{\log \text { rank }}=0.028\right.$ and $\mathrm{p}^{\log \text { rank }}=$ 0.036 , respectively). Stratified by stage, this finding held true for $\mathrm{p} 27$ expression in $\mathrm{pTa}$ and $\mathrm{pT} 1$ tumors $\left(\mathrm{p}^{\log \text { rank }}=\right.$ 0.039 and $p^{\text {log rank }}=0.014$, respectively; fig. $2 b-d$ ). In addition, p16 expression in $>1.5 \%$ of tumor cells showed an association with a better OS in low-grade (mean OS 103 months, median survival was not reached) and pTa tumors (mean OS 109 months, median survival was not reached) compared to p16 expression in $<1.5 \%$ of tumor cells (mean OS 63 months, median OS 72 months and mean OS 73 months, median OS 84 months, respectively; $\mathrm{p}=0.043$ and $\mathrm{p}=0.019$, respectively; fig. $3 \mathrm{a}, \mathrm{b}$ ).

Multivariate analysis for OS considering age, grade, stage, number of recurrences, Ki-67, p53, p27 and p16 revealed that only increased age (relative risk $=1.062,95 \%$ CI 1.108-1.018, $\mathrm{p}=0.005$ ), low number of recurrences (relative risk $=0.682,95 \%$ CI 0.499-0.933, $\mathrm{p}=0.017$ ) and p53 expression in $>14 \%$ (relative risk $=1.026,95 \%$ CI 

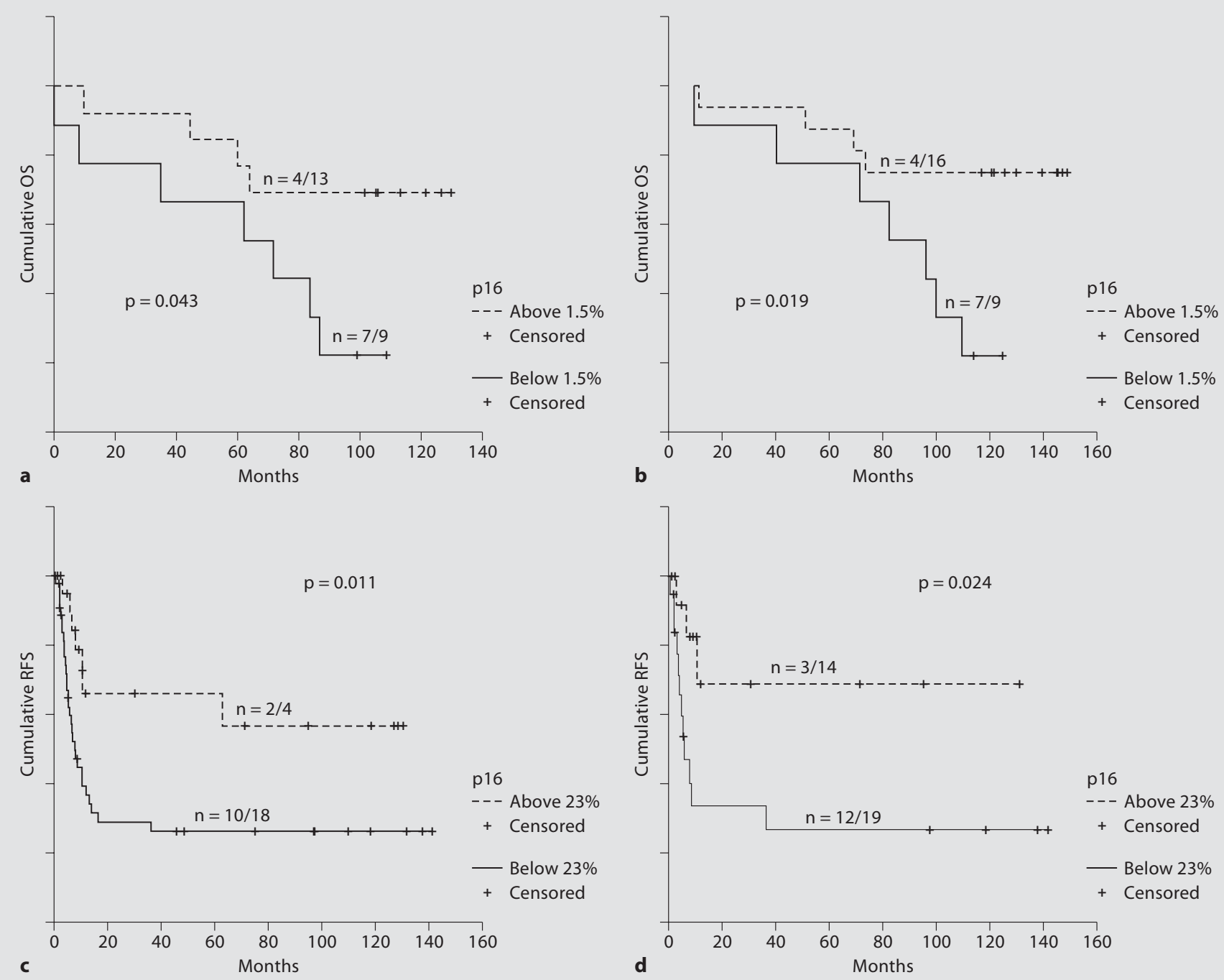

Fig. 3. Expression of p16 above the cutoff is significantly associated with a better OS in low-grade (a) and pTa (b) tumors and predicts a better RFS in high-grade (c) and pT2-4 tumors (d). p16 $<1.5 \%$ versus p16 $>1.5 \%$ and p16 $<23 \%$ versus p16 $>23 \%$ compared by the log rank test. $n=$ Number of events/number of cases.

$1.008-1.044, \mathrm{p}=0.004)$ were independent predictors of a worse OS.

\section{Recurrence-Free Survival}

Ki-67 expression in $>8.75 \%$ of tumor cells was associated with a shorter RFS when compared to tumors with Ki-67 expression in $<8.75 \%$. Patients with PCNA expression of more than $74 \%$ had a longer RFS than those with PCNA expression below 74\%. Similarly, Bcl-2, CCNE and p16 expression above the cutoff was associated with a bet- ter RFS (table 4). Considering all other known clinical and morphological parameters, only progress at relapse was associated with a worse RFS [18].

Stratified by grade and stage, PCNA expression above the cutoff was associated with a longer RFS only in highgrade tumors $\left(\mathrm{p}^{\log \text { rank }}=0.023\right)$. CCNE expression above the cutoff was only associated with a better RFS in highgrade $\left(\mathrm{p}^{\log \text { rank }}=0.02\right), \mathrm{pTa}\left(\mathrm{p}^{\log \text { rank }}=0.043\right)$ and $\mathrm{pT} 1$ tumors $\left(\mathrm{p}^{\log \text { rank }}=0.008\right)$. Expression of p16 above the cutoff predicted a longer RFS in high-grade $\left(\mathrm{p}^{\log \text { rank }}=\right.$ 
0.011 ) and pT2-4 tumors ( $\mathrm{p}^{\log \text { rank }}=0.024$; fig. $3 \mathrm{c}, \mathrm{d}$ ). Bcl-2 expression above the cutoff was a predictor for a better RFS in low-grade $\left(\mathrm{p}^{\log \text { rank }}=0.0005\right)$ and $\mathrm{pTa}$ tumors $\left(\mathrm{p}^{\log \text { rank }}=0.0001\right)$. Ki-67 did not show any association with RFS when either stratified for grade or stage.

Multivariate analysis for RFS considering progressive disease, Ki-67, PCNA, CCNE, p16 and Bcl-2 showed that only lacking progressive disease (relative risk $=0.234$, 95\% CI 0.109-0.503, $\mathrm{p}<0.001$ ), Bcl-2 (relative risk $=$ $0.978,95 \%$ CI $0.958-0.998, \mathrm{p}=0.032$ ) and CCNE expression (relative risk $=0.983,95 \%$ CI $0.966-0.999, \mathrm{p}=0.04$ ) were independent prognostic factors considering better RFS.

\section{Discussion}

In UC a variety of studies have investigated cell cycle markers for their predictive value concerning diseasefree, overall and disease-specific survival, but results often remained contradictory $[2,10]$. Possible reasons include the heterogeneity of evaluated cases in different studies. Another important point is the use of different cutoffs for marker positivity, with only few studies determining the optimal cutoff values by ROC, rather than by stepwise analysis or by median or mean percentages of positively staining cells $[6,7,12]$. Similarly to previous studies, increased expression of Ki-67 and p53 proved to be associated with a worse OS in our collective [4, 12, 15-17]. Indeed, p53 mutations have been suggested as a key event in the development of aggressive UC phenotype [23].

A particular new aspect of our study concerns the prognostic value of $\mathrm{p} 16$ and $\mathrm{p} 27$ protein expression. p16 was assessed as nuclear and cytoplasmic staining, as previously reported, though some authors regard cytoplasmic staining for p16 as nonspecific [20]. Nuclear expression of p16 above the cutoff values was associated with a better OS in low-grade and low-stage tumors and predicted a better RFS in high-grade and high-stage tumors in our patient cohort. Hitchings et al. [20] and Korkolopoulou et al. [24], who studied the influence of p16 on disease survival and progression, emphasized the protective effect of p16 in UC, especially in tumors without p53 accumulation and normal expression of p16, which is in accordance with our finding of improved OS in lowgrade and pTa tumors, believed to lack p53 mutations [23]. Indeed, p16 promotor hypermethylations resulting in inactivation are more frequently observed in invasive than noninvasive tumors, indicating that inactivation of p16 is associated with a more aggressive phenotype, but the reported hypermethylation frequencies in UC of the bladder vary considerably $[9,25]$. Additionally, lost p16 expression could also be due to deletions at 9p21, which are commonly observed in UC, but such deletions are as frequent or even more frequent in pTa and low-grade tumors compared to high-grade tumors [9, 26, 27]. Thus, retained p16 expression in UC, as observed in our cohort, may identify a distinct subgroup of both low- and highgrade as well as low- and high-stage UC patients without p16 gene alterations, which are probably accompanied by a better prognosis. Strong cytoplasmic p16 staining was often seen in high-grade tumors (all with accompanying nuclear staining), pointing towards a probable deregulation leading to cytoplasmic retention of p16, analogously to p27 [21]. Nevertheless, in our study RFS was better in these patients as well and one may speculate that cytoplasmic p16 accumulation could simply reflect a compensatory mechanism to overcome other defects in cell cycle regulation. We observed a negative correlation between p16 and CCND1 expression. Loss of p16 and high CCND1 has been shown to be associated with hyperphosphorylated retinoblastoma protein, resulting in increased cell proliferation [8]. Intact p16 could probably counterbalance the oncogenic potential of CCND1 in UC $[2,4,8]$. Interestingly in that consideration, we observed a tendency towards better OS for patients with CCND1 expression and several authors have linked CCND1 expression to low grade, low stage and better OS, too $[2,5]$. It seems likely that the proposed oncogenic role of CCND1 can be modified, particularly in UC, by alterations in other cell cycle-controlling molecules, such as loss of p16 or p53 mutations. Such complex interactions may probably be responsible for the observed association of CCND1 expression with subsequent UC progression despite its potential positive prognostic importance considering OS $[4,6]$.

Loss of p27 in bladder cancer has been reported to indicate a worse prognosis in UC [28]. In contrast, we showed that p27 expression in $>5.5 \%$ of tumor cells is associated with worse OS in high-grade and $\mathrm{pTa} / \mathrm{pT} 1$ tumors. Expression of p27 has been reported to be associated with an adverse disease outcome in diffuse large $B$ cell lymphomas and posttranslational modifications were found to be responsible for the loss of the growthinhibitory function of p27 despite its cellular accumulation [21, 29]. Increased p27 expression in superficial highgrade tumors may probably represent accumulation of a nonfunctional protein, which is supported by the pres- 
ence of cytoplasmic p27 staining in some cases in our study. The impact of p27 on prognosis only in high-grade $\mathrm{pTa} / \mathrm{pT} 1$ UCs further underlines differences between superficial low- and high-grade tumors. In addition, we observed a correlation of $\mathrm{p} 27$ and CCNE expression. Loss of p27 expression has been reported to be associated with loss of CCNE expression and a more aggressive tumor phenotype $[3,28,30]$. Indeed, high CCNE expression has been linked to a longer disease-specific survival and a lower risk of recurrence in UC $[3,30]$. In our study, a better RFS in tumors with CCNE expression above the cutoff could be found, but no prognostic significance of CCNE concerning OS. On the other hand, gains of the CCNE gene have been detected in high-grade tumors, suggesting CCNE as a potential oncogene [30]. This finding is supported by several studies in other cancer types [3135]. Therefore, we speculate that the impact of CCNE on prognosis probably depends on its expression causes (gene amplification, degradation failure, supraordinal cascades) and the functional state of p27 or other cell cycle regulatory molecules, including p53 and p21.

The prognostic value of other cell cycle-related proteins remains contradictory. Bcl-2, though associated with a better RFS, correlated with p53 accumulation, strongly suggesting complex interactions, which are reflected in the conflicting results on its prognostic impact obtained in different studies [14, 36, 37]. PCNA, though associated with Ki-67 expression, predicted a better RFS in high-grade tumors, which may be due to the interaction with other molecules, such as p21, modulating its functional activity [38].

To summarize, our results based on standardized analysis approaches suggest complex partially redundant, partially concurrent interactions between the proteins involved in cell cycle control, proliferation and apoptosis in UC and point towards the role of p16- and p27-associated pathways. However, profound changes in complementary or concurrent complex cell cycle control pathways probably result in different impacts of single molecules on disease outcome. Therefore, though studies on the expression of cell cycle markers may result in new insights of their function, the use of these molecules as prognostic markers still needs to be particularly prospectively evaluated.

\section{Acknowledgements}

We thank H. Muehlboeck from the Cancer Registry of Tyrol/ Austria, Institute for Epidemiology of TILAK for providing epidemiologic data, B. Sterlacci, MD for editorial assistance and S. Jöbstl for technical assistance.

\section{References}

1 Gillett CE, Barnes DM: Demystified ... cell cycle. Mol Pathol 1998;51:310-316.

-2 Sgambato A, Migaldi M, Faraglia B, De Aloysio G, Ferrari P, Ardito R, De Gaetani C, Capelli G, Cittadini A, Trentini GP: Cyclin D1 expression in papillary superficial bladder cancer: its association with other cell cycleassociated proteins, cell proliferation and clinical outcome. Int J Cancer 2002;97:671678.

-3 Shariat SF, Ashfaq R, Sagalowsky AI, Lotan Y: Correlation of cyclin D1 and E1 expression with bladder cancer presence, invasion, progression, and metastasis. Hum Pathol 2006; 37:1568-1576.

4 Lopez-Beltran A, Luque RJ, Alvarez-Kindelan J, Quintero A, Merlo F, Requena MJ, Montironi R: Prognostic factors in survival of patients with stage Ta and T1 bladder urothelial tumors: the role of G1-S modulators (p53, p21Waf1, p27Kip1, cyclin D1, and cyclin D3), proliferation index, and clinicopathologic parameters. Am J Clin Pathol 2004;122:444-452.
5 Tut VM, Braithwaite KL, Angus B, Neal DE, Lunec J, Mellon JK: Cyclin D1 expression in transitional cell carcinoma of the bladder: correlation with p53, waf1, pRb and Ki67. Br J Cancer 2001;84:270-275.

6 Yurakh AO, Ramos D, Calabuig-Farinas S, Lopez-Guerrero JA, Rubio J, Solsona E, Romanenko AM, Vozianov A, Pellin A, Llombart-Bosch A: Molecular and immunohistochemical analysis of the prognostic value of cell-cycle regulators in urothelial neoplasms of the bladder. Eur Urol 2006;50:506-515.

7 Ong F, Moonen LM, Gallee MP, ten Bosch C, Zerp SF, Hart AAM, Bartelink H, Verheij M: Prognostic factors in transitional cell cancer of the bladder: an emerging role for Bcl-2 and p53. Radiother Oncol 2001;61:169-175.

$\checkmark 8$ Mitra AP, Datar RH, Cote RJ: Molecular pathways in invasive bladder cancer: new insights into mechanisms, progression, and target identification. J Clin Oncol 2006;24: 5552-5564.
-9 Berggren P, Kumar R, Sakano S, Hemminki L, Wada T, Steineck G, Adolfsson J, Larsson P, Norming U, Wijkstrom $\mathrm{H}$, Hemminki K: Detecting homozygous deletions in the $C D K N 2 A\left(p 16^{I N K 4 a}\right) / A R F\left(p 14^{A R F}\right)$ gene in urinary bladder cancer using real-time quantitative PCR. Clin Cancer Res 2003;9:235242

10 Wagner U, Suess K, Luginbuhl T, Schmid U, Ackermann D, Zellweger T, Maurer R, Alund G, Knönagel H, Rist M, Jordan P, Moch H, Mihatsch MJ, Gasser TC, Sauter G: Cyclin D1 overexpression lacks prognostic significance in superficial urinary bladder cancer. J Pathol 1999;188:44-50.

11 Liukkonen T, Lipponen P, Raitanen M, Kaasinen E, Ala-Opas M, Rajala P, Kosma VM: Evaluation of p21WAF1/CIP1 and cyclin D1 expression in the progression of superficial bladder cancer. Finbladder Group. Urol Res 2000;28:285-292.

12 Dybowski B, Kupryjanczyk J, Rembiszewska A, Pykalo R, Borkowski A: P27 ${ }^{\text {Kipl }}$ and Ki-67 expression analysis in transitional cell carcinoma of the bladder. Urol Res 2003;31:397401 . 
13 Doganay L, Altaner S, Bilgi S, Kaya E, Ekuklu G, Kutlu K: Expression of the cyclin-dependent kinase inhibitor p27 in transitional cell bladder cancers: is it a good predictor for tumor behavior? Int Urol Nephrol 2003;35: 181-188.

14 Galmozzi F, Rubagotti A, Romagnoli A, Carmignani G, Perdelli L, Gatteschi B, Boccardo F: Prognostic value of cell cycle regulatory proteins in muscle-infiltrating bladder cancer. J Cancer Res Clin Oncol 2006;132:757764.

15 Wu TT, Chen JH, Lee YH, Huang JK: The role of bcl-2, p53, and ki-67 index in predicting tumor recurrence for low grade superficial transitional cell bladder carcinoma. J Urol 2000;163:758-760.

- 16 Santos LL, Amaro T, Pereira SA. Lameiras CR, Lopes P, Bento MJ, Oliveira J, Criado B, Lopes CS: Ki-67 index enhances the prognostic accuracy of the urothelial superficial bladder carcinoma risk group classification. Int J Cancer 2003; 105:267-272.

-17 Zlotta AR, Noel JC, Fayt I, Drowart A, Van Vooren JP, Huygen K, Simon J, Schulmann CC: Correlation and prognostic significance of p53, p21WAF1/CIP1 and Ki-67 expression in patients with superficial bladder tumors treated with bacillus Calmette-Guérin intravesical therapy. J Urol 1999;161:792-798.

- 18 Brunner A, Ensinger C, Christiansen M, Heiss S, Verdorfer I, Mikuz G, Tzankov A: Expression and prognostic significance of Tetranectin in invasive and non-invasive bladder cancer. Virchows Arch 2007;450: 659-664.

-19 Tzankov A, Went P, Zimpfer A, Dirnhofer S: Tissue microarray technology: principles, pitfalls and perspectives - lessons learned from hematological malignancies. Exp Gerontol 2005;40:737-744.

20 Hitchings AW, Kumar M, Jordan S, Nargund V, Martin J, Berney DM: Prediction of progression in pTa and pT1 bladder carcinomas with p53, p16 and pRb. Br J Cancer 2004;91: 552-557.

-21 Saez A, Sanchez E, Sanchez-Beato M, Cruz MA, Chacon I, Munoz E, Camacho FI, Martinez-Montero JC, Mollejo M, Garcia JF, Piris MA: $\mathrm{p} 27^{\mathrm{KIP} 1}$ is abnormally expressed in diffuse large B-cell lymphomas and is associated with an adverse clinical outcome. $\mathrm{Br} \mathrm{J}$ Cancer 1999;80:1427-1434.
22 Perkins NJ, Schisterman EF: The inconsistency of 'optimal' cutpoints obtained using two criteria based on the receiver operating characteristic curve. Am J Epidemiol 2006; 163:670-675.

23 Mhawech-Fauceglia P, Cheney RT, Schwaller $\mathrm{J}$ : Genetic alterations in urothelial bladder carcinoma: an updated review. Cancer 2006; 106:1205-1216

24 Korkolopoulou P, Christodoulou P, Lazaris A, Thomas-Tsagli E, Kapralos P, Papanikolaou A, Kalliteraki P, Daveris P: Prognostic implications of aberrations in $\mathrm{p} 16 / \mathrm{pRb}$ pathway in urothelial bladder carcinomas: a multivariate analysis including p53 expression and proliferation markers. Eur Urol 2001;39: 167-177.

25 Kawamoto K, Enokide H, Gotande T, Kubo H, Nishiyama K, Kawahara M, Nakagawa M: p16INK4a and p14ARF methylation as a potential biomarker for human bladder cancer. Biochem Biophys Res Commun 2006;339: 790-796.

26 Orlow I, Lacombe L, Hannon GJ, Serrano M, Pellicer I, Dalbagni G, Reuter VE, Zhang ZF, Beach D, Cordon-Cardo C: Deletion of the p16 and p15 genes in human bladder tumors. J Natl Cancer Inst 1995;87:1524-1529.

27 Cairns P, Shaw ME, Knowles MA: Initiation of bladder cancer may involve deletion of a tumour-suppressor gene on chromosome 9. Oncogene 1993;8:1083-1085.

28 Kamai T, Takagi K, Asami H, Ito Y, Oshima $\mathrm{H}$, Yoshida KI: Decreasing of $\mathrm{p} 27^{\mathrm{Kip} 1}$ and cyclin E protein levels is associated with progression from superficial into invasive bladder cancer Br J Cancer 2001;84:1242-1251.

29 Zhang W, Bergamaschi D, Jin B, Lu X: Posttranslational modifications of p27kip1 determine its binding specificity to different cyclins and cyclin-dependent kinases in vivo. Blood 2005;105:3691-3698.

30 Richter J, Wagner U, Kononen J, Fijan A, Bruderer J, Schmid U, Ackermann D, Maurer R, Alund G, Knönagl H, Rist M, Wilber $\mathrm{K}$, Anabitarte M, Hering F, Hardmeier T, Schönenberger A, Flury R, Jäger P, Fehr JL, Schraml P, Moch H, Mihatsch MJ, Gasser T, Kallioniemi OP, Sauter G: High-throughput tissue microarray analysis of cyclin E gene amplification and overexpression in urinary bladder cancer. Am J Pathol 2000;157:787794.
31 Yoo J, Jung JH, Lee MA, Seo KJ, Shim BY, Kim SH, Cho DG, Ahn MI, Kim CH, Cho KD, Kang SJ, Kim HK: Immunohistochemical analysis of non-small cell lung cancer: correlation with clinical parameters and prognosis. J Korean Med Sci 2007;22:318325 .

32 Porter PL, Barlow WE, Yeh IT, Lin MG, Yuan XP, Donato E, Sledge GW, Shapiro CL, Ingle JN, Haskell CM, Albain KS, Roberts JM, Livingston RB, Hayes DF: $27^{\text {Kip1 }}$ and cyclin E expression and breast cancer survival after treatment with adjuvant chemotherapy. J Natl Cancer Inst 2006;98:1723-1731.

-33 Skalicky DA, Kench JG, Segara D, Coleman MJ, Sutherland RL, Henshall SM, Musgrove EA, Biankin AV: Cyclin E expression and outcome in pancreatic ductal adenocarcinoma. Cancer Epidemiol Biomarkers Prev 2006;15:1941-1947.

34 Rosen DG, Yang G, Deavers MT, Malpica A, Kavanagh JJ, Mills GB, Liu J: Cyclin E expression is correlated with tumor progression and predicts a poor prognosis in patients with ovarian carcinoma. Cancer 2006; 106:1925-1932.

35 Tzankov A, Gschwendtner A, Augustin F, Fiegl M, Obermann EC, Dirnhofer S, Went P: Diffuse large B-cell lymphoma with overexpression of cyclin $\mathrm{E}$ substantiates poor standard treatment response and inferior outcome. Clin Cancer Res 2006;12:21252132.

- 36 Vollmer RT, Humphrey PA, Swanson PE, Wick MR, Hudson ML: Invasion of the bladder by transitional cell carcinoma: its relation to histologic grade and expression of p53, MIB-1, c-erb B-2, epidermal growth factor receptor, and bcl-2. Cancer 1998;82:715723.

37 Amirghofran Z, Monabati A, Khezri A, Malek-Hosseini Z: Apoptosis in transitional cell carcinoma of bladder and its relation to proliferation and expression of $\mathrm{p} 53$ and bcl2. Pathol Oncol Res 2004;10:154-158.

38 Smith ND, Rubenstein JN, Eggener SE, Kozlowski JM: The p53 tumor suppressor gene and nuclear protein: basic science review and relevance in the management of bladder cancer. J Urol 2003;169:1219-1228. 